https://russjcardiol.elpub.ru

doi:10.15829/1560-4071-2020-3879

ISSN 1560-4071 (print)

ISSN 2618-7620 (online)

\title{
Comparison of Cardiopulmonary Exercise Capacity in Patients with Atrial Septal Defect Treated with Minimally Invasive Cardiac Surgery or Transcatheter Closure
}

Hicaz Zencirkiran Agus, Serkan Kahraman, Mehmet Erturk, Burak Onan, Ali Kemal Kalkan, Ahmet Guner, Ali Birand, Fatih Uzun, Mehmet Emin Kalkan, Mustafa Yildiz

Aim. The main aim of our study was to compare the results of transcatheter atrial septal defect (ASD) closure versus minimally invasive cardiac surgery (MICS) focusing on cardiopulmonary exercise capacity and echocardiographic findings preoperatively and 1 month after defect closure.

Material and methods. 54 patients with ASD and finally 43 patients who were followed up were included in the study. 21 patients were in MICS (robotic or endoscopic approach) and 22 patients were in transcatheter closure arm. All patients investigated in detail by transesophageal echocardiography and underwent cardiopulmonary exercise test (CPET). At the end of first month, CPET and transthorasic echocardiography were reperformed.

Results. There was significant improvement of physical capacity after 1 month following the transcatheter closure procedure documented by exercise time and $\mathrm{VO}_{2}$ max. Tricuspid annular plane systolic excursion (TAPSE) and tricuspid lateral annular systolic velocity (Tri S) were not changed. In surgery group right heart diameters declined significantly; but $\mathrm{VO}_{2} \max$, TAPSE and Tri S significantly decreased

Conclusion. Cardiopulmonary exercise function is increased in transcatheter closure group 1 month after closure and contrary not in MICS group. This may be caused by long recovery time of the right ventricle after surgery. Device closure of ASD is preferable to surgical closure if the anatomy is suitable. However, MICS for ASD closure is safe, with short recovery period and less scarring.

Key words: atrial septal defect, cardiopulmonary exercise test, minimally invasive surgical procedures, transcatheter closure.

Relationships and Activities: none

University of Health Sciences Mehmet Akif Ersoy Thoracic and Cardiovascular Surgery Center Training and Research Hospital, Istanbul, Turkey.

Hicaz Zencirkiran Agus* - MD, Department of Cardiology, ORCID: 0000-00025882-0525, Serkan Kahraman - MD, Department of Cardiology, ORCID: 0000-
0003-2796-0987, Mehmet Erturk - MD, Department of Cardiology, ORCID: 00000002-2468-2793, Burak Onan - MD, Department of Cardiovascular Surgery, ORCID: 0000-0003-1392-992X, Ali Kemal Kalkan - MD, Department of Cardiology, ORCID: 0000-0003-3553-7468, Ahmet Guner - MD, Department of Cardiology, ORCID: 00000001-6517-7278, Ali Birand - MD, Department of Cardiology, ORCID: 0000-00026621-0380, Fatih Uzun - MD, Department of Cardiology, ORCID: 0000-0001-9252735X, Mehmet Emin Kalkan - MD, Department of Cardiology, ORCID: 0000-00026569-3827, Mustafa Yildiz - PhD, Department of Cardiology, ORCID: 0000-0003$3502-4785$

${ }^{*}$ Corresponding author: hicazincir@yahoo.com

ASD - atrial septal defect, AT - anaerobic threshold, CPBT - cardiopulmonary bypass time, CPET - cardiopulmonary exercise test, EF - ejection fraction, MICS minimally invasive cardiac surgery, PAPs - pulmonary artery systolic pressure, RA right atrium, RER - relative exchange ratio, RV — right ventricle, TAPSE - tricuspid annular plane systolic excursion, TEE - transesophageal echocardiography, TTE transthorasic echocardiography, Tri S - tricuspid annular systolic velocity, XCT aortic cross-clemping time, $\mathrm{VE}$ - ventilatory efficiency, $\mathrm{VO}_{2}$ max - maximal oxygen consumption.

Received: 03.05.2020

Revision Received: 20.06.2020

Accepted: 25.06 .2020

(cc) BY 4.0

For citation: Hicaz Zencirkiran Agus, Serkan Kahraman, Mehmet Erturk, Burak Onan, Ali Kemal Kalkan, Ahmet Guner, Ali Birand, Fatih Uzun, Mehmet Emin Kalkan, Mustafa Yildiz. Comparison of Cardiopulmonary Exercise Capacity in Patients with Atrial Septal Defect Treated with Minimally Invasive Cardiac Surgery or Transcatheter Closure. Russian Journal of Cardiology. 2020;25(8):3879. doi:10.15829/15604071-2020-3879

\section{Сравнение толерантности к физической нагрузке у пациентов, подвергнутых малоинвазивной хирургической или транскатетерной коррекции дефекта межпредсердной перегородки}

Hicaz Zencirkiran Agus, Serkan Kahraman, Mehmet Erturk, Burak Onan, Ali Kemal Kalkan, Ahmet Guner, Ali Birand, Fatih Uzun, Mehmet Emin Kalkan, Mustafa Yildiz

Цель. Сравнить эффективность малоинвазивной хирургической и транскатетерной коррекции дефекта межпредсердной перегородки (ДМпП) по данным кардиопульмонального нагрузочного теста и эхокардиографии (ЭхоКГ), выполненной до операции и месяц спустя.

Материал и методы. В исследование были включены 54 пациента с ДМПП, данные о 43 из которых были доступны к концу исследования. 21 пациент был подвергнут малоинвазивному вмешательству (роботизированный или эндоскопический методы) и 22 пациента - транскатетерному закрытию. Все пациенты были детально обследованы с помощью чреспищеводной ЭхоКГ и прошли кардиопульмонарный нагрузочный тест (КПНТ). В конце первого месяца были повторно выполнены КПНТ и трансторакальная ЭхоКГ. Результаты. Через 1 месяц после транскатетерной коррекции ДМПП наблюдалось значительное улучшение толерантности к физической нагрузке в виде увеличения длительности нагрузочной пробы и значения максимального потребления кислорода ( $\left.\mathrm{VO}_{2} \mathrm{max}\right)$. Систолическая экскурсия кольца трехстворчатого клапана (tricuspid annular plane systolic excursion, TAPSE) и систолическая скорость движения кольца трехстворчатого клапана (tricuspid lateral annular systolic velocity, Tri S) не изменились. Хотя в группе малоинвазивного вмешательства диаметры правых отделов сердца значительно уменьшились, тем не менее, $\mathrm{VO}_{2}$ max, TAPSE и Tri S значительно снизились.

Заключение. Результаты КПНТ значительно улучшились в группе транскатетерной коррекции ДМПП через 1 месяц после вмешательства и, наоборот, в группе малоинвазивной кардиохирургии. Это может быть связано с длительным сроком восстановления правого желудочка после операции. При отсутствии анатомических особенностей, не позволяющих выполнять транскатетерное закрытие дМПп, оно является более предпочтительным, чем хирурги- 
ческое вмешательство. Тем не менее, малоинвазивное хирургическое вмешательство является относительно безопасным методом, характеризующимся коротким периодом восстановления и меньшим количеством рубцов.

Ключевые слова: дефект межпредсердной перегородки, кардиопульмонарный нагрузочный тест, малоинвазивные хирургические вмешательства, транскатетерное закрытие.

Отношения и деятельность: нет.

Научно-исследовательский институт торакальной и сердечно-сосудистой хирургии имени Мехмета Акифа Эрсоя, Стамбул, Турция.

Hicaz Zencirkiran Agus* - MD, Department of Cardiology, ORCID: 0000-00025882-0525, Serkan Kahraman - MD, Department of Cardiology, ORCID: 00000003-2796-0987, Mehmet Erturk - MD, Department of Cardiology, ORCID: 00000002-2468-2793, Burak Onan - MD, Department of Cardiovascular Surgery, ORCID: 0000-0003-1392-992X, Ali Kemal Kalkan - MD, Department of Cardiology, ORCID: 0000-0003-3553-7468, Ahmet Guner - MD, Department of Cardiology, ORCID:

Atrial septal defect (ASD) of secundum type is one of the most common forms of congenital heart disease in adults. ASD results in additional flow through the right atrium (RA), the right ventricle (RV), and the pulmonary circulation. This is usually well tolerated for a prolonged period of time. The diagnosis is frequently made in adulthood. The most common presenting symptoms at adult age are palpitations, exertional dyspnea or fatigue, which increases with age [1]. Closure of atrial septal defects either percutaneously or surgically is indicated in patients with a hemodynamically significant shunt that causes enlargement of the right heart [2]. Complications include atrial arrhythmia, RV failure, and pulmonary arterial hypertension (PAH) if not repaired by early adulthood [1]. When RV is no more than moderately dilated before closure, there is little concern about persistent clinically relevant RV dysfunction. Additionally, while most patients have resolution of RV dilation, it may persist and maximal exercise capacity may remain impaired in long term follow-up, in a sizable subset of patients [3].

Surgical treatment of ASD has been practiced for over fifty years and appears to be a safe and effective procedure. Surgical treatment of ASD could be through median sternotomy, small thoracotomy with endoscopic support and with robotic assistance. Transcatheter closure of ASD with the ASD Septal Occluder has become a feasible alternative to conventional surgical closure in selected patients [4]. Transcatheter closure has the advantage of avoiding the need for sternotomy, cardiopulmonary bypass and intensive care stay, facilitates rapid patient recovery and confers financial returns. There are some limitations for transcatheter ASD closure such as anatomical and device-related. Main limitations to transcatheter ASD closure may be insufficient surrounding rims, primum or sinus venosus-type defects, multiple or associated defects and excessively bulging atrial septal aneurisms (ASA).

There are only a few studies comparing the results of surgical and transcatheter ASD closure [5-7]. The main
0000-0001-6517-7278, Ali Birand - MD, Department of Cardiology, ORCID: 00000002-6621-0380, Fatih Uzun - MD, Department of Cardiology, ORCID: 0000-00019252-735X, Mehmet Emin Kalkan - MD, Department of Cardiology, ORCID: 00000002-6569-3827, Mustafa Yildiz - PhD, Department of Cardiology, ORCID: 00000003-3502-4785.

*Автор, ответственный за переписку (Corresponding author): hicazincir@yahoo.com

Рукопись получена 03.05.2020

Рецензия получена 20.06.2020

Принята к публикации 25.06.2020

Для цитирования: Hicaz Zencirkiran Agus, Serkan Kahraman, Mehmet Erturk Burak Onan, Ali Kemal Kalkan, Ahmet Guner, Ali Birand, Fatih Uzun, Mehmet Emin Kalkan, Mustafa Yildiz. Сравнение толерантности к физической нагрузке у пациентов, подвергнутых малоинвазивной хирургической или транскатетерной коррекции дефекта межпредсердной перегородки. Российский кардиологический журнал. 2020;25(8):3879. (In Engl.) doi:10.15829/1560-4071-2020-3879

aim of our study was to compare the results of transcatheter ASD closure versus minimally invasive cardiac surgery (MICS) focusing on cardiopulmonary exercise capacity and echocardiographic findings preoperatively and 1 month after defect closure.

\section{Material and methods}

Study population. We prospectively included 54 patients with ostium secundum ASD in our institution between September 2018 and July 2019. This study protocol was approved by the local ethics committee and informed consent was obtained from all individual participants. They underwent closure, either surgical or transcatheter using the Amplatzer Septal Occluder (ASO). Patients with coronary heart disease, moderate or severe valvular heart disease, pulmonary vascular resistance greater than two thirds of systemic vascular resistance, defect size $>40 \mathrm{~mm}$, other congenital heart disease and those unable to exercise were excluded. Patients with small ASD with a left-to-right shunt (Qp/Qs) of less than 1,5:1, sinus venosus ASD including partial anomalous pulmonary venous drainage, who did not have enlargement of the right heart diameters or pulmonary hypertension at rest and during exercise, without clinical symptoms of heart failure and without paradoxical embolism, did not receive an ASD closure in accordance to AHA guidelines [8]. 11 patients who did not undergo cardiopulmonary exercise test at first month were excluded from the study. Consequently, we included totally 43 patients; 21 patients who had surgery and 22 patients who had transcatheter closure.

All patients with ASD were investigated in detail by transesophageal echocardiography (TEE). Cases of ASD with a TEE diameter of $30 \mathrm{~mm}$ or less with a septal rim of at least $5 \mathrm{~mm}$ and non-floppy were considered suitable for transcatheter closure. Patients who objected for percutaneous closure, those who had single defect too large for occlusion and multiple defects unsuitable for interventional closure were randomized to surgery. All 
patients underwent to cardiopulmonary exercise test (CPET). At the end of first month CPET and transthoracic echocardiography (TTE) were reperformed.

Surgical closure. The minimal invasive endoscopic approach or Da Vinci SI robotic surgery system (Intuitive Surgical, Inc, Sunnyvale, CA, USA) without sternotomy was used. For minimal invasive endoscopic approach, the main working port and port for surgical endoscope were placed with skin incision. For Da Vinci SI robotic surgery, mini-thoracotomy was used for pericardiotomy, deployment of cardioplegic cannula, left ventricular drainage by using of the instruments and 3D-endoscope of da Vinci complex and assistant's work during the main surgical stage. In our cohort 7 patients were undergone port access endoscopic approach and 14 patients were undergone robotic surgery.

Transcatheter closure. Transcatheter closure of ASD using an Amplatzer Septal Occluder device (AGA Medical Corporation; Plymouth, MN, USA) was performed under general anesthesia with the assistance of TEE. Hemodynamic evaluation was performed before ASD closure. An exchange guide wire was placed in a left pulmonary vein. The appropriate size device was then screwed on the cable and advanced inside the proper size sheath. Its position as well as stability was assessed by fluoroscopy and TEE. All patients were instructed about infective endocarditis prophylaxis for six months after device placement. Aspirin 81-100 mg and clopidogrel was initiated $48 \mathrm{~h}$ before closure and continued for three months thereafter.

Echocardiography. Measurements of LV and RV internal dimensions obtained according to American Society of Echocardiography recommendations with an Epic 7 Ultrasound System (TTE Philips Healthcare, Andover, MA). To minimize inter-observer and intraobserver variations, one trained person performed all examinations. Two measurements of the RV were made in the apical four-chamber view: RV short-axis dimension (RV1), defined as the maximal dimension from the right septal surface to the free wall perpendicular to the long axis; and maximal RV long-axis dimension (RV2), defined as the distance between the RV apex and the mid-point of the tricuspid valve. RA was measured as apicobasal (RA1) and mediolateral (RA2) from apical four-chamber view. All patients were in normal sinus rhythm. In every patient the pulmonary-to-systemic flow ratio (Qp/Qs) was calculated, and right ventricular systolic pressure (RVSP) was measured in patients with tricuspid valve regurgitation using the simplified Bernoulli formula. All patients underwent TEE to characterize the ASD, measure the maximal ASD diameter and the surrounding rims.

Cardiopulmonary exercise test (CPET). A total of 54 patients with ASD had a treadmill exercise ergospirometry test based on a Bruce protocol (Ergometrics 900, Ergoline, Bitz, Germany). Breath-to-breath measurements of expired gas values were analysed. Heart rate, blood pressure and ventilation were recorded continuously during ergospirometry. We measured ventilatory flow, inspiratory and expiratory oxygen concentration difference, expiratory carbon dioxide concentration. From these variables oxygen uptake, peak oxygen uptake, carbon dioxide delivery, respiratory exchange ratio (RER) and ventilatory equivalents for oxygen and carbon dioxide $\left(\mathrm{VE} / \mathrm{VO}_{2}, \mathrm{VE} /\right.$ $\mathrm{VCO}_{2}$ ) were calculated by machine. Patients were encouraged to exercise to exhaustion or to a respiratory exchange ratio $\geqslant 1,0$. $\mathrm{VO}_{2}$ max was defined as the amount of oxygen consumed by the body at the peak of tolerable exercise. The anaerobic threshold (AT) was determined from the plot of carbon dioxide output $\left(\mathrm{VCO}_{2}\right)$ against oxygen uptake $\left(\mathrm{VO}_{2}\right)$, where the slope of this linear relation increased owing to a rise in $\mathrm{VCO}_{2}$ (V-slope method); or $\mathrm{VO}_{2}$ at the onset of blood lactate accumulation. At this time, there is a significant increase in blood lactate concentration. $\mathrm{VE} / \mathrm{VO}_{2}$ and $\mathrm{VE} / \mathrm{VCO}_{2}$ was defined as ventilator efficiency [9].

Statistical Analysis. Statistical analysis was made using the computer software Statistical Package for Social Sciences (IBM SPSS Statistics for Windows, version 21.0. released 2012, IBM Corp., Armonk, New York, USA). Fisher's exact test and Pearson chi-square analysis were performed for categorical variables. Fitness to normal distribution was analyzed with the Shapiro Wilk test. Data was expressed as "mean \pm standard deviation (SD)" for variables with normal distribution, "median $\left(15^{\text {th }}-75^{\text {th }}\right)$ " for variables without normal distribution and "n (\%)" for categorical variables. Mann-Whitney $U$ test was used for comparing quantitative variables with abnormal distribution while Student t-test was used for comparing the means between two groups with normal distribution. Paired sample t test was used for related samples with normal distribution while Wilcoxon matchedpair signed rank test was used for related samples with skewed distribution. A p-value $<0,05$ was considered statistically significant.

\section{Results}

Among 54 patients with ASD, 43 patients who were followed up were included in the study. Patients' demographic, echocardiographic and exercise data are summarized in Table 1. Median age in 21 patients undergoing MICS was 34 (24-49) with 52,4\% being female; whereas in 22 patients undergoing transcatheter closure the median age was 51 (32-57) with $63,6 \%$ being female. In surgery group 1 patient was hypertensive, 1 patient was diabetic; in closure group no patient was diabetic, 5 patients were hypertensive. The median ASD size was 20 (18-28) $\mathrm{mm}$ in surgery group and 16,5 (14-20) $\mathrm{mm}$ in transcatheter group. The size of the ASD was larger and the Qp/Qs ratio was higher in the MICS group; because patients with large ASD were not suitable for transcatheter closure and were referred to surgery. $\mathrm{VO}_{2} \max$ was higher in MICS group. No clinical or statistical differences were found in echocardiography and 
Table 1

Baseline, demographic, echocardiographic and cardiopulmonary exercise test data for patients in surgical and transcatheter closure groups

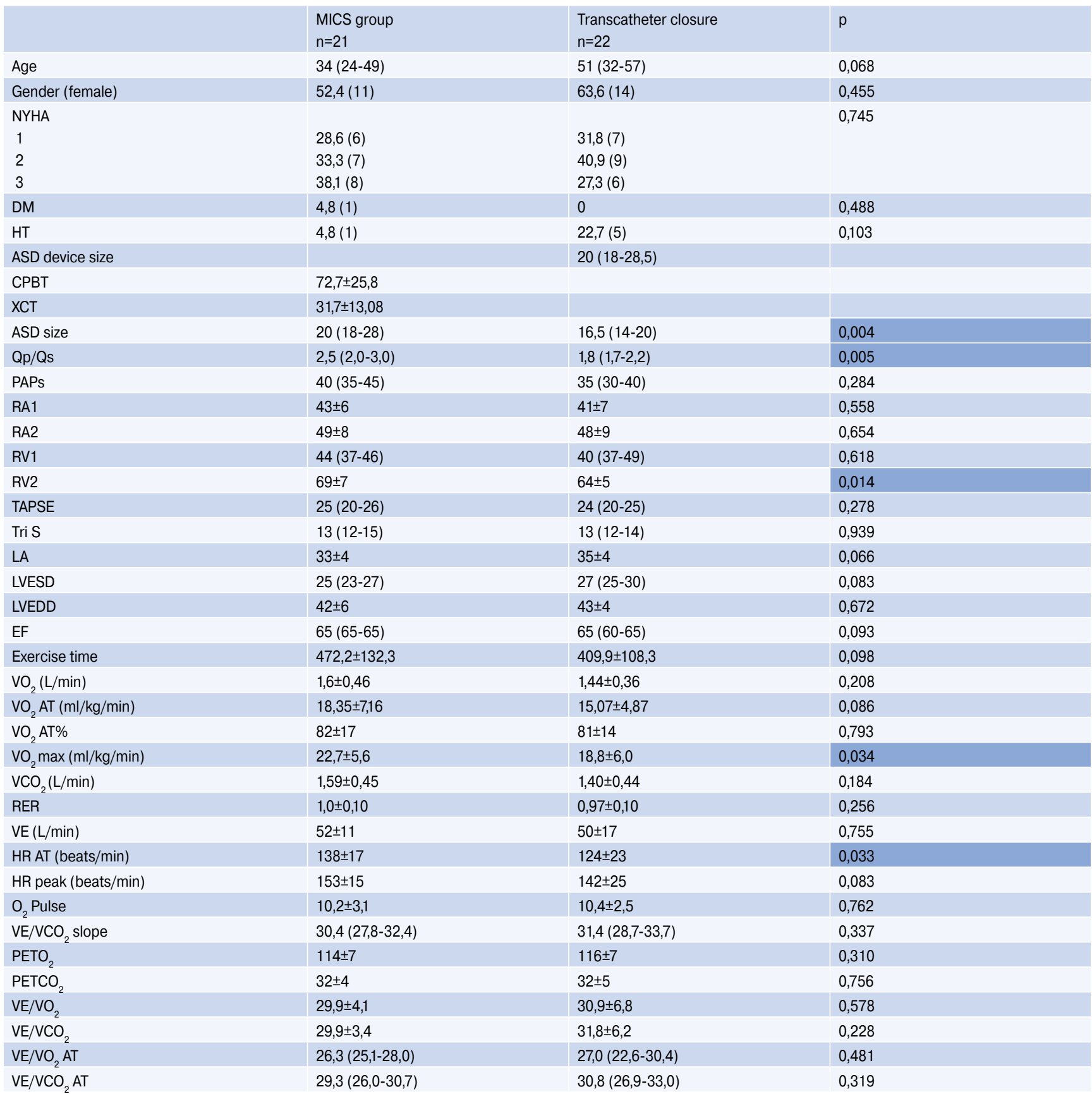

Note: data are expressed as mean \pm standard deviation and median (interquartile range) or absolute number (percentage).

Abbreviations: ASD - atrial septal defect, CPBT - cardiopulmonary bypass time, DM - diabetes mellitus, EF - ejection fraction, HR - heart rate, HT - hypertension, LA - left atrium, LVESD - left ventricle end-systolic diameter, LVEDD - left ventricle end-diastolic diameter, min — minutes, NYHA - New York Heart Association, PAPs pulmonary artery systolic pressure, RA - right atrium, RER - relative exchange ratio, RV - right ventricle, TAPSE — tricuspid annular plane systolic excursion, Tri S — tricuspid lateral annular systolic velocity, $\mathrm{VE}$ - ventilatory efficiency, $\mathrm{VO}_{2}$ max - maximal oxygen consumption, $\mathrm{VCO}_{2}-$ production of carbon dioxide, $\mathrm{VE} / \mathrm{VCO}_{2}-$ ventilatory equivalent for $\mathrm{CO}_{2}, \mathrm{VE} / \mathrm{VO}_{2}$ - ventilatory equivalent for $\mathrm{O}_{2}, \mathrm{VO}_{2} \mathrm{AT}-$ oxygen consumption in at anaerobic threshold, XCT - aortic cross-clamping time.

cardiopulmonary functional capacity parameters between MICS and transcatheter closure group except for RV and $\mathrm{VO}_{2}$ max. Total cardiopulmonary bypass time (CPBT) averaged $72,7 \pm 25,8 \mathrm{~min}$ and aortic cross-clamping time
(XCT) was $31,7 \pm 13,08$. The median diameter of implanted devices was $20(18-28,5) \mathrm{mm}$.

Preoperatively $\mathrm{VO}_{2} \max (\mathrm{ml} / \mathrm{kg} / \mathrm{min})$ was $22,7 \pm 5,6$ in MICS and 18,8 $\pm 6,0$ in transcatheter group. Exercise time 
Table 2

Transthoracic Echocardiography and Cardiopulmonary Exercise Testing at Baseline and After Transcatheter Closure of Atrial Septal Defect $(n=22)$

\begin{tabular}{|c|c|c|c|}
\hline & Baseline & 1 month & $p$ \\
\hline Exercise time & $405(350-495)$ & $465(382,75-601,75)$ & 0,002 \\
\hline $\mathrm{VO}_{2}(\mathrm{~L} / \mathrm{min})$ & $1,43 \pm 0,36$ & $1,56 \pm 0,42$ & 0,011 \\
\hline $\mathrm{VO}_{2} \mathrm{AT}(\mathrm{ml} / \mathrm{kg} / \mathrm{min})$ & $15,06 \pm 4,87$ & $14,42 \pm 4,65$ & 0,415 \\
\hline $\mathrm{VO}_{2} \mathrm{AT} \%$ & $80,5(70,5-94,25)$ & $74(61,25-86,0)$ & 0,013 \\
\hline $\mathrm{VO}_{2} \max (\mathrm{ml} / \mathrm{kg} / \mathrm{min})$ & $18,78 \pm 6,00$ & $20,37 \pm 6,45$ & 0,014 \\
\hline $\mathrm{VCO}_{2}$ & $1,39(1,09-1,62)$ & $1,52(1,23-1,70)$ & 0,015 \\
\hline RER & $0,96 \pm 0,101$ & $0,99 \pm 0,07$ & 0,149 \\
\hline $\operatorname{VE}(\mathrm{L} / \mathrm{min})$ & $50,45 \pm 17,44$ & $56,77 \pm 18,6$ & 0,016 \\
\hline HR AT (beats/min) & $135(105,5-140,25)$ & $117(102-136)$ & 0,273 \\
\hline HR peak (beats/min) & $141,7 \pm 25,4$ & $141,5 \pm 24,6$ & 0,919 \\
\hline $\mathrm{O}_{2}$ Pulse & $10,43 \pm 2,54$ & $11,27 \pm 3,35$ & 0,041 \\
\hline VE/ $\mathrm{VCO}_{2}$ slope & $31,4(28,42-33,7)$ & $31,5(28,6-35,2)$ & 0,404 \\
\hline $\mathrm{PETO}_{2}$ & $115,8 \pm 6,98$ & $115,71 \pm 7,28$ & 0,957 \\
\hline $\mathrm{PETCO}_{2}$ & $31,5 \pm 5,26$ & $30,09 \pm 4,63$ & 0,166 \\
\hline $\mathrm{VE} / \mathrm{VCO}_{2}$ & $31,78 \pm 6,18$ & $32,5 \pm 6,51$ & 0,417 \\
\hline $\mathrm{VE} / \mathrm{VO}_{2} \mathrm{AT}$ & $28,16 \pm 6,61$ & $25,9 \pm 5,85$ & 0,005 \\
\hline $\mathrm{VE} / \mathrm{VCO}_{2} \mathrm{AT}$ & $30,85 \pm 6,04$ & $31,25 \pm 6,50$ & 0,582 \\
\hline PAPs & $36,7 \pm 6,31$ & $28,9 \pm 7,19$ & $<0,001$ \\
\hline RA1 & $41,3 \pm 7,02$ & $37,5 \pm 7,35$ & 0,002 \\
\hline RA2 & $47,5(40,0-53,0)$ & $40(39,25-49,25)$ & $<0,001$ \\
\hline RV1 & $40(36,75-49,25)$ & $36,5(34,5-40,0)$ & 0,001 \\
\hline RV2 & $64,5(50-68)$ & $60(56,5-62,75)$ & $<0,001$ \\
\hline TAPSE & $27,7 \pm 3,36$ & $23,5 \pm 1,96$ & 0,289 \\
\hline Tris & $13(12-14)$ & $13(12-14$ & 0,791 \\
\hline LA & $35,05 \pm 4,06$ & $34,6 \pm 4,02$ & 0,609 \\
\hline LVESD & $26,5(25-30)$ & $28(26,5-31)$ & 0,060 \\
\hline LVEDD & $42(40-45,25)$ & $42(40-45,25)$ & 0,792 \\
\hline EF & $65(60-65)$ & $65(60-65)$ & 0,914 \\
\hline
\end{tabular}

Abbreviations: EF - ejection fraction, LA - left atrium, LVESD - left ventricle end-systolic diameter, LVEDD - left ventricle end-diastolic diameter, PAPs - pulmonary artery systolic pressure, RA — right atrium, RER - relative exchange ratio, RV - right ventricle, TAPSE - tricuspid annular plane systolic excursion, Tri S - tricuspid annular systolic velocity, $\mathrm{VE}$ - ventilatory efficiency, $\mathrm{VO}_{2}$ max - maximal oxygen consumption, $\mathrm{VCO}_{2}$ - production of carbon dioxide, $\mathrm{VE} / \mathrm{VCO}{ }_{2}-$ ventilatory equivalent for $\mathrm{CO}_{2}$, $\mathrm{VE} /$ $\mathrm{VO}_{2}$ - ventilatory equivalent for $\mathrm{O}_{2}, \mathrm{VO}_{2} \mathrm{AT}-$ oxygen consumption at anaerobic threshold, min - minutes.
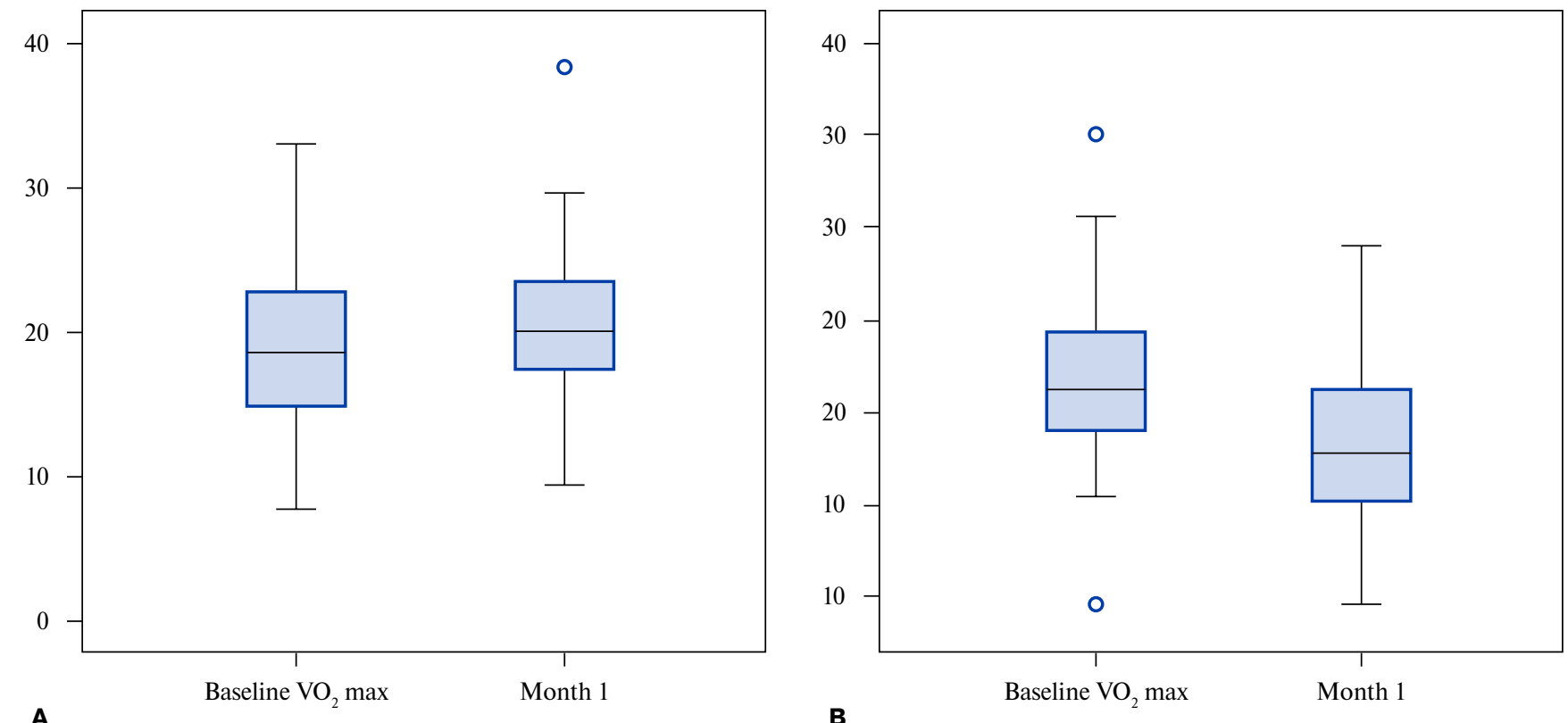

Figure 1. Box-plot representations of maximal $\mathrm{VO}_{2}(\mathrm{ml} / \mathrm{kg} / \mathrm{min})$ at baseline and 1 month after procedure in transcatheter $(\mathbf{A})$ and minimal invasive surgery $(\mathbf{B})$ groups. 
Table 3

\section{Transthoracic Echocardiography and Cardiopulmonary Exercise Testing at Baseline and After Surgical Closure of Atrial Septal Defect $(n=21)$}

\begin{tabular}{|c|c|c|c|}
\hline & Baseline & 1 month & $\mathrm{p}$ \\
\hline Exercise time & $482(440-550)$ & $491(419,5-580)$ & 0,940 \\
\hline $\mathrm{VO}_{2}(\mathrm{~L} / \mathrm{min})$ & $1,5 \pm 0,45$ & $1,43 \pm 0,42$ & 0,013 \\
\hline $\mathrm{VO}_{2}$ AT $(\mathrm{ml} / \mathrm{kg} / \mathrm{min})$ & $18,3 \pm 7,16$ & $16,56 \pm 5,57$ & 0,141 \\
\hline $\mathrm{VO}_{2} \mathrm{AT} \%$ & $84(70,0-97,5)$ & $81(71-92)$ & 0,687 \\
\hline $\mathrm{VO}_{2} \max (\mathrm{ml} / \mathrm{kg} / \mathrm{min})$ & $22,6 \pm 5,57$ & $19,9 \pm 5,11$ & 0,006 \\
\hline $\mathrm{VCO}_{2}(\mathrm{~L} / \mathrm{min})$ & $1,5(1,25-2,04)$ & $1,46(1,07-1,79)$ & 0,117 \\
\hline RER & $1,00 \pm 0,09$ & $1,02 \pm 0,078$ & 0,312 \\
\hline $\mathrm{VE}(\mathrm{L} / \mathrm{min})$ & $51,8 \pm 11,3$ & $48,1 \pm 12,4$ & 0,069 \\
\hline HR AT (beats/min) & $139(124,5-153,5)$ & $125(107-141)$ & 0,028 \\
\hline HR peak (beats/min) & $153,1 \pm 15,4$ & $143,3 \pm 19,9$ & 0,003 \\
\hline $\mathrm{O}_{2}$ Pulse & $10,1 \pm 3,14$ & $16,6 \pm 30,6$ & 0,331 \\
\hline VE/ $\mathrm{VCO}_{2}$ slope & $30,4(27,7-32,6)$ & $29,9(27,1-31,4)$ & 0,192 \\
\hline $\mathrm{PETO}_{2}$ & $113,7 \pm 6,6$ & $114,3 \pm 7,86$ & 0,662 \\
\hline $\mathrm{VE} / \mathrm{VO}_{2}$ & $29,9 \pm 4,07$ & $29,9 \pm 4,78$ & 0,976 \\
\hline $\mathrm{VE} / \mathrm{VCO}_{2}$ & $29,9 \pm 3,44$ & $29,16 \pm 3,98$ & 0,326 \\
\hline $\mathrm{VE} / \mathrm{VO}_{2} \mathrm{AT}$ & $25,9 \pm 4,19$ & $26,44 \pm 5,56$ & 0,763 \\
\hline $\mathrm{VEVCO}_{2}$ AT & $28,6 \pm 4,11$ & $28,68 \pm 4,31$ & 0,990 \\
\hline PAPs & $38,9 \pm 8,12$ & $27,28 \pm 5,93$ & $<0,001$ \\
\hline RA1 & $42,5 \pm 6,33$ & $36,6 \pm 6,46$ & $<0,001$ \\
\hline RA2 & $50(45-55)$ & $42(38-46,5)$ & $<0,001$ \\
\hline RV1 & $44(36-47,5)$ & $37(33-40)$ & 0,002 \\
\hline $\mathrm{RV} 2$ & $68(66-74,5)$ & $63(58-69)$ & 0,001 \\
\hline TAPSE & $23,9 \pm 3,49$ & $16,71 \pm 3,57$ & $<0,001$ \\
\hline Tri S & $13(12-15)$ & $10,0(10-11)$ & $<0,001$ \\
\hline LA & $32,7 \pm 4,01$ & $33,52 \pm 4,61$ & 0,420 \\
\hline EF & $65(65-65)$ & $65(60-65)$ & 0,066 \\
\hline
\end{tabular}

Abbreviations: EF - ejection fraction, LA - left atrium, LVESD - left ventricle end-systolic diameter, LVEDD - left ventricle end-diastolic diameter, PAPs - pulmonary artery systolic pressure, RA — right atrium, RER - relative exchange ratio, RV - right ventricle, TAPSE - tricuspid annular plane systolic excursion, Tri S - tricuspid annular systolic velocity, $\mathrm{VE}$ - ventilatory efficiency, $\mathrm{VO}_{2}$ max - maximal oxygen consumption, $\mathrm{VCO}_{2}$ - production of carbon dioxide, $\mathrm{VE} / \mathrm{VCO}-\mathrm{ventilatory}$ equivalent for $\mathrm{CO}_{2}$, $\mathrm{VE} /$ $\mathrm{VO}_{2}$ - ventilatory equivalent for $\mathrm{O}_{2}, \mathrm{VO}_{2} \mathrm{AT}-$ oxygen consumption at anaerobic threshold, min - minutes.

was $472,2 \pm 132,3$ in preoperative surgery group and $409,9 \pm 108,3$ in another group.

Data obtained by TTE and cardiopulmonary exercise testing at baseline and 1 month after the procedure are summarized for two groups in Table 2 and 3.

Transcatheter closure group. There was a significant improvement of physical capacity after 1 month following the procedure documented by exercise time, $\mathrm{VO}_{2} \max$, $\mathrm{VO}_{2}$, VE (minute ventilation), and $\mathrm{O}_{2}$ pulse (Table 2, Figure 1A). CPET at first month after the procedure demonstrated longer exercise time (405 (350-495) vs 465 $(382,75-601,75)$ second $p=0,02)$, increased maximal oxygen consumption $(18,78 \pm 6,00$ vs $20,37 \pm 6,45 p=0,014)$, increased VE from $50,45 \pm 17,44$ to $56,77 \pm 18,6 \mathrm{~L} / \mathrm{min}$ $(\mathrm{p}=0,016)$. And also, $\mathrm{O}_{2}$ pulse $\left(\mathrm{VO}_{2} / \mathrm{HR}\right)$ increased significantly from $10,43 \pm 2,54$ to $11,27 \pm 3,35 \mathrm{ml}$ $(p=0,041) . V E / \mathrm{VCO}_{2}$ slope which is important for prognosis didn't change in both groups. Heart rate (HR) at anaerobic threshold decreased in both groups. Right atrium, right ventricle, pulmonary artery pressure decreased after transcatheter closure significantly as expected. Tricuspid annular plane systolic excursion (TAPSE) and tricuspid lateral annular systolic velocity (Tri S) were not changed but were both in normal range. There was no difference in left ventricular ejection fraction in either group. One patient in transcatheter arm had acute atrial fibrillation postoperatively and returned to sinus rhythm spontaneously.

Surgery group. Cardiopulmonary functional exercise and echocardiographic parameters before and 1 month later are shown in Table 3. Exercise time increased but it didn't reach statistically significance. $\mathrm{VO}_{2}$ max decreased 


\section{Comparison of changes in CPET and echocardiographic parameters in the surgical and transcatheter groups at 1-month follow-up}

\begin{tabular}{|c|c|c|c|}
\hline & MICS group & Transcatheter closure & $\mathrm{p}$ \\
\hline $\mathrm{VO}_{2}(\mathrm{~L} / \mathrm{min})$ & $-0,17 \pm 0,28$ & $0,13 \pm 0,21$ & $<0,001$ \\
\hline $\mathrm{VO}_{2} \mathrm{AT}(\mathrm{ml} / \mathrm{kg} / \mathrm{min})$ & $-1,78 \pm 5,32$ & $-0,64 \pm 3,61$ & 0,419 \\
\hline $\mathrm{VO}_{2} \mathrm{AT} \%$ & $0,00(-9,0-6,0)$ & $-7,0(-12,0-0,0)$ & 0,145 \\
\hline $\mathrm{VO}_{2} \max (\mathrm{ml} / \mathrm{kg} / \mathrm{min})$ & $-2,67 \pm 3,98$ & $1,59 \pm 2,77$ & $<0,001$ \\
\hline $\mathrm{VCO}_{2}(\mathrm{~L} / \mathrm{min})$ & $-0,10(-0,30-0,06)$ & $0,15(-0,03-0,35)$ & 0,005 \\
\hline $\mathrm{O}_{2}$ Pulse & $6,43 \pm 29,58$ & $0,84 \pm 1,80$ & 0,381 \\
\hline VE/ $\mathrm{VCO}_{2}$ slope & $-0,87 \pm 3,48$ & $0,92 \pm 4,63$ & 0,160 \\
\hline $\mathrm{PETO}_{2}$ & $0,95 \pm 9,29$ & $-0,10 \pm 8,05$ & 0,706 \\
\hline RA1 & $-5,86 \pm 4,0$ & $-3,82 \pm 4,94$ & 0,146 \\
\hline RA2 & $-7,0(-10,0--4,0)$ & $-3,0(-5,0--2,0)$ & 0,100 \\
\hline RV1 & $-4,0(-10,0--2,0)$ & $-4,0(-6,0--0,0)$ & 0,341 \\
\hline RV2 & $-8,0(-10,0--4,0)$ & $-4,0(-5,0--2,0)$ & 0,025 \\
\hline TAPSE & $-7,19 \pm 4,85$ & $0,82 \pm 3,53$ & $<0,001$ \\
\hline
\end{tabular}

Abbreviations: RA — right atrium, RV - right ventricle, TAPSE — tricuspid annular plane systolic excursion, Tri S — tricuspid annular systolic velocity, VE — ventilatory efficiency, $\mathrm{VO}_{2}$ max - maximal oxygen consumption, $\mathrm{VCO}_{2}$ - production of carbon dioxide, $\mathrm{VE} / \mathrm{VCO}_{2}-$ ventilatory equivalent for $\mathrm{CO}_{2}$, $\mathrm{VO}{ }_{2} \mathrm{AT}_{-}-$oxygen consumption at anaerobic threshold, $\min -$ minutes.

from $22,6 \pm 5,57$ to $19,9 \pm 5,11 \mathrm{ml} / \mathrm{kg} / \mathrm{min} \quad(\mathrm{p}=0,006)$ (Figure 1B). In accordance with this, TAPSE $(23,9 \pm 3,49$ vs $16,71 \pm 3,57 \mathrm{p}<0,001)$ and Tri $\mathrm{S}(13(12-15)$ vs $10,0(10-$ 11) $\mathrm{p}<0,001)$ significantly decreased. Worsening of the right ventricle function can explain the deterioration of CPET parameters in surgery group. Right heart diameters and PAPs declined meaningfully. 1 patient underwent to reoperation for pericardial effusion in MICS group and the follow up was uneventful.

Table 4 compares the changes in CPET and echocardiographic parameters in surgical and transcatheter groups at 1-month follow-up. There were significant differences in $\mathrm{VO}_{2}$ max and right ventricle parameters between the surgical and percutaneous groups.

\section{Discussion}

This prospective study provides evidence that $\mathrm{VO}_{2}$ max, which is an important indicator of exercise capacity, is increased in transcatheter closure arm 1 month after closure. On the contrary cardiopulmonary and right ventricle functions were decreased in MICS group at first month evaluation. This reduction can be explained by the fact that one month is too short to recover from surgery. At first month, the general condition of the patients in surgical group was good and wound healing was achieved due to having minimally invasive surgery. Symptomatic improvement was seen in all patients and the follow-up period was uneventful. Exercise time was also increased in surgery group, but was not statistically significant. These results suggest that cardiopulmonary exercise functions may be better in the surgical group if the exercise test was performed 6 months or 1 year after surgery. The lack of increase in $\mathrm{VO}_{2}$ max at first month does not translate to absence of improvement in ASD patients undergone surgery. Furthermore, left ventricle and left atrium diameters increased non-significantly after closure or surgery, due to increased volume loading of the LV, as well as to an improved ventricular interaction. In our study ASD size and Qp/Qs were greater in MICS group which may cause bias; however, in order to avoid bias, we compared the groups among themselves and compared the changes between both groups.

Currently the transcatheter closure of ASD is common practice. Its main advantages are, absence of a surgical scar, shorter hospitalization time and being able to avoid general anesthesia [10, 11]. Study results of Komar M, et al. demonstrate that device closure of ASD in the elderly is technically easy, safe, and has minimal complications [12]. However, complications associated with this procedure for atrial septal defects have been reported including device embolization, thrombosis, device malposition, and cerebrovascular events. In a previous study including 30 patients, it was shown that transcatheter closure was safe and effective treatment for atrial septal defects and could be an alternative option to open heart surgery [13]. Additionally, echocardiographic data demonstrated a decrease in right ventricular and right atrium area, suggesting that atrial septal occlusion improved volume overload of the right heart [13]. In a recently published meta-analysis of Mylonas KS, et al., authors concluded that MICS constitutes a viable alternative to transcatheter repair and should be considered as an option for hemodynamically significant ASDs [14]. According to data published in 2018 by Prochownik P, et al., 
improvement of right heart chambers was observed already after 1 month following the transcatheter procedure. At 24-month follow-up higher maximal oxygen consumption was evident [15]. In contrast, Helber U, et al. observed an increase in $\mathrm{VO}_{2}$ max only after 10 years, and no notable effects within the first 4 months in ASD patients undergone surgical closure, as in our study [16].

Several trials indicated a significant reduction of PAPs and improvement of exercise capacity after correction of ASD. In patients with elevated pulmonary vascular resistance and irreversible damage to the pulmonary arterioles might prevent the improvement of postoperative exercise capacity in patients with left to right shunt and high pulmonary arterial pressure. In a study of Kobayashi et al. there was a significant negative correlation between Qp:Qs and peak $\mathrm{VO}_{2}$, besides that exercise capacity in patients with large left-to-right shunt increased after surgical closure of ASD (mean 4,6 2,0 months) [17].

In transcatheter ASD closure group Dhillon R, et al. observed improvement of right ventricular functions 6-12-months after ASD closure [18]. In most patients the size of right heart chambers returned to normal in a 24-month follow-up, which was also shown in a study of Zhong-Dong ZD, et al. [19]. Stephensen SS, et al. said that elderly patients with diastolic dysfunction, larger shunts and sedentary people may need longer time to adapt to the new physiology; furthermore, patients with smaller shunts in their transcatheter closure series had larger improvement in predicted exercise capacity [20]. Santos M, et al. demonstrated the presence of distinctly abnormal RV and pulmonary vascular responses to exercise in a subset of patients after successful ASD closure, despite normal resting hemodynamics [21]. In another study ASD closure led to a significant reduction in stress-induced pulmonary hypertension and right heart diameters indicating reverse $\mathrm{RV}$ remodeling but the $\mathrm{VO}_{2}$ max did not change after ASD closure [22]. Takaya Y, et al. evaluated short- and long-term benefits of transcatheter closure of

\section{References}

1. Murphy JG, Gersh BJ, McGoon MD, et al. Long-term outcome after surgical repair of isolated atrial septal defect: follow-up at 27 to 32 years. N Engl J Med. 1990;323(24):164550. doi:10.1056/NEJM199012133232401.

2. Warnes CA, Williams RG, Bashore TM, et al. ACC/AHA 2008 guidelines for the management of adults with congenital heart disease: a report of the American College of Cardiology/ American Heart Association Task Force on Practice Guidelines (Writing Committee to Develop Guidelines on the Management of Adults With Congenital Heart Disease). J Am Coll Cardiol. 2008;52:e143-263. doi:10.1016/j.jacc.2008.10.001.

3. Cuypers JA, Opić P, Menting ME, et al. The unnatural history of an atrial septal defect: longitudinal 35 year follow up after surgical closure at young age. Heart. 2013:99(18):1346-52. doi:10.1136/heartinl-2013-304225.

4. Pedra CA, Pedra SR, Esteves CA, et al. Trancatheter closure of secundum atrial septal defects with complex anatomy. J Invas Cardiol. 2004;16:117-22.

5. Du ZD, Hijazi ZM, Kleinman ChS, et al. Amplatzer Investigators. Comparison Between Transcatheter and Surgical Closure of Secundum Atrial Septal Defect in Children and Adults. Results of Multicenter Nonrandomized Trial. J Am Coll Cardiol. 2002;39:1836-44. doi:10.1016/s0735-1097(02)01862-4.

6. Berger F, Vogel M, Alexi-Meskishvili V, et al. Comparison of Results and Complications of Surgical and Amplatzer Device Closure of Atrial Septal Defect. J Thorac Cardiovasc Surg. 1999;118:674-80. discussion 678-80. doi:10.1016/S0022-5223(99)70013-9.
ASD in patients older than 40 years and found that peak $\mathrm{VO}_{2}$ did not change at 1 and 3 months, but it improved significantly after 6 months [23]. Suchon E, et al. compared surgical and ASO (Amplatzer septal occlusion) groups at 1-year follow up and indicated that $\mathrm{VE} / \mathrm{CO}_{2}$ slope decreased more in the ASO than in the surgical group [24]. Despite increased VE/VCO slope has been proven to be a strong predictor of mortality, we couldn't see statistically difference in our analysis. This may be due to early evaluation of postoperative patients with cardiopulmonary exercise test.

Limitations. The major limitation of our study is, short follow-up period. We aimed to include defect size and functional capacity matched groups, however there was difference between two groups due to referring patients with bigger ASD size to surgery in clinical practice. Ventricle function and functional capacity could be better estimated if study data was supported by catheterization, magnetic resonance imaging and strain. Another limitation was a relatively small sample size.

\section{Conclusion}

To the best of our knowledge, our study is rare in its use of cardiopulmonary exercise functions before and after ASD closure comparing transcatheter closure and minimally invasive cardiac surgery. Cardiopulmonary exercise function is increased in transcatheter closure group 1 month after closure and contrary not in MICS group. This may be caused by long recovery time of the right ventricle after surgery. We suggest that device closure of ASD is preferable to surgical closure if the anatomy is suitable. However, MICS for ASD closure is safe, with short recovery period and less scarring. Additionally, minimally invasive cardiac surgery may be preferred over sternotomy; due to shorter hospital stay, rapid recovery and lack of sternotomy in ASD patients unsuitable for transcatheter closure.

\section{Relationships and Activities: none.}

7. Rosas M, Zabal C, Garcia-Montes J, et al. Transcatheter versus surgical closure of secundum atrial septal defect in adults: impact of age at intervention. A concurrent matched comparative study. Congenit Heart Dis. 2007;2:148-55. doi:10.1111/j.17470803.2007.00091.x

8. Stout KK, Daniels CJ, Aboulhosn JA, et al. 2018 AHA/ACC Guideline for the Management of Adults With Congenital Heart Disease: A Report of the American College of Cardiology/ American Heart Association Task Force on Clinical Practice Guidelines. J Am Coll Cardiol. 2019;73:e81-e192. doi:10.1016/j.jacc.2018.08.1029.

9. Tran D. Cardiopulmonary Exercise Testing. Methods Mol Biol. 2018;1735:285-95 doi:10.1007/978-1-4939-7614-0_18.

10. Yang MC, Wu JR. Recent review of transcatheter closure of atrial septal defect. Kaohsiung J Med Sci. 2018;34(7):363-9. doi:10.1016/j.kjms.2018.05.001.

11. Attie F, Rosas M, Granados N, et al. Surgical treatment for secundum atrial septal defects in patients $>40$ years old. A randomized clinical trial. J Am Coll Cardiol. 2001;38:2035-42. doi:10.1016/s0735-1097(01)01635-7.

12. Komar M, Przewlocki T, Olszowska M, et al. The benefit of atrial septal defect closure in elderly patients. Clin Interv Aging . 2014;9:1101-7. doi:10.2147/CIA.S62313.

13. Kobayashi A, Kunii $\mathrm{H}$, Yokokawa $\mathrm{T}$, et al. Safety and effectiveness of transcatheter closure of atrial septal defects: Initial results in Fukushima Prefecture. Fukushima J. Med. Sci. 2018;64(3):151-6. doi:10.5387/fms.2018-13. 
14. Mylonas KS, Ziogas IA, Evangeliou A, et al. Minimally Invasive Surgery vs Device Closure for Atrial Septal Defects: A Systematic Review and Meta-analysis. Pediatr Cardiol. 2020;10.1007/s00246-020-02341-y. doi:10.1007/s00246-020-02341-y. [online ahead of print]

15. Prochownik P, Przewłock $\mathrm{T}$, Podolec $\mathrm{P}$, et al. Improvement of physical capacity in patients undergoing transcatheter closure of atrial septal defects. Adv Interv Cardiol. 2018;14,1(51):90-4. doi:10.5114/aic.2018.74360.

16. Helber U, Bauman R, Sebold $\mathrm{H}$, et al. Atrial septal defect in adults: cardiopulmonary exercise capacity before and 4 months and 10 years after defect closure. J Am Coll Cardiol. 1997;29:1345-50. doi:10.1016/s0735-1097(97)00058-2.

17. Kobayashi $\mathrm{Y}, \mathrm{Nakanishi} \mathrm{N}$, Kosakai Y. Pre- and postoperative exercise capacity associated with hemodynamics in adult patients with atrial septal defect: A retrospective study. Eur $\mathrm{J}$ Cardiothorac Surg . 1997;11(6):1062-6. doi:10.1016/s1010-7940(96)01131-1.

18. Dhillon $R$, Josen $M$, Henein M, et al. Transcatheter closure of atrial septal defect preserves right ventricular function. Heart. 2002;87(5):461-5. doi:10.1136/heart.87.5.461.

19. Du ZD, Cao QL, Koenig P, et al. Speed of normalization of right ventricular volume overload after transcatheter closure of atrial septal defect in children and adults. Am J Cardiol. 2001;88(12):1450-3, A9. doi:10.1016/s0002-9149(01)02135-x.
20. Stephensen SS, Ostenfeld E, Kutty S, et al. Transcatheter closure of atrial septal defect in adults: time-course of atrial and ventricular remodeling and effects on exercise capacity. Int J Cardiovasc Imaging. 2019;35(11):2077-84. doi:10.1007/s10554-019-01647-0.

21. Santos M, Systrom D, Epstein SE, et al. Impaired exercise capacity following atrial septal defect closure: an invasive study of the right heart and pulmonary circulation. Pulm Circ 2014;4(4):630-7. doi:10.1086/678509.

22. Lange SA, Braun MU, Schoen SP, et al. Latent pulmonary hypertension in atrial septal defect: Dynamic stress echocardiography reveals unapparent pulmonary hypertension and confirms rapid normalization after ASD closure. Neth Heart J. 2013;21:333-43. doi:10.1007/s12471-013-0425-8

23. Takaya $\mathrm{Y}$, Taniguchi M, Akagi T, et al. Long-term effects of transcatheter closure of atrial septal defect on cardiac remodeling and exercise capacity in patients older than 40 years with a reduction in cardiopulmonary function. J Interv Cardiol. 2013; 26:195-9. doi:10.1111/joic.12002.

24. Suchon E, Pieculewicz M, Tracz W, et al. Transcatheter closure as an alternative and equivalent method to the surgical treatment of atrial septal defect in adults: comparison of early and late results. Med Sci Monit. 2009;15:CR612-7. 